\title{
Dynamics of Nitrifiers in Soils of Intensively Vegetable Cultivated Areas in Sri Lanka
}

\author{
K.K.K. Nawarathna ${ }^{1}$, W.S. Dandeniya ${ }^{2 *}$, R.S. Dharmakeerthi ${ }^{2}$ and P. Weerasinghe ${ }^{1}$ \\ Postgraduate Institute of Agriculture \\ University of Peradeniya \\ Sri Lanka
}

\begin{abstract}
Nitrification tend to reduce the agronomic fertilizer use efficiency in cropping systems because nitrate, the end product of nitrification, has high potential to loss from soil environment due to denitrification and leaching. The population characteristics of ammonia oxidizing and nitrite oxidizing microorganisms carrying out nitrification in soils may affect the effectiveness of approaches taken to suppress nitrification. A study was conducted to assess the activity and abundance of nitrifiers in soils of intensively vegetable grown regions in Sri Lanka. Soil samples were collected from 72 locations across Nuwara Eliya, Marassana, Kalpitiya and Gannoruwa representing vegetable cultivated fields managed conventionally $(n=45)$ and organically $(n=9)$, and uncultivated areas $(n=18)$. Basic soil characteristics were determined using standard procedures. Potential nitrification rate (PNR) and the abundance of ammonia oxidizers and nitrite oxidizers were estimated. Chemical characteristics of soils varied widely with $\mathrm{pH}, \mathrm{EC}$ and organic $\mathrm{C} \%$ ranging from 3.8 to $8.5,0.04$ to $0.94 \mathrm{dS} / \mathrm{m}$ and $0.9 \%$ to $4.5 \%$, respectively. The PNR of the studied soils ranged from 0.18 to $15.80 \mathrm{NO}_{3}^{-}$$\mathrm{N} / \mathrm{kg} / \mathrm{h}$. The abundance of ammonia oxidizers and nitrite oxidizers ranged from 1.96 to 5.97 $\log _{10} \mathrm{CFU} \mathrm{g} \mathrm{g}^{-1}$ and 1.36 to $5.63 \log _{10} \mathrm{CFU} \mathrm{g} \mathrm{g}^{-1}$, respectively. The potential activity of nitrifiers did not correlate with the abundance of ammonia oxidizers or nitrite oxidizers. Thus, the functional and compositional diversities of nitrifying communities may be different across the soils. PNR values for studied soils are higher compared to reported values in literature. Hence, appropriate measures need to be taken to suppress nitrification as high nitrification rates could lead to reduce fertilizer use efficiency and increase risk of groundwater contamination with nitrate.
\end{abstract}

Keywords: Fertilizer use efficiency, potential nitrification rate, soil nitrifiers, vegetable cultivation

\section{INTRODUCTION}

Nearly $11 \%$ of the $\mathrm{N}$-fertilizers (urea and ammonium sulphate) imported to Sri Lanka is being consumed by vegetable sector, only second to tea sector (27\%) from among the systems that dominates cultivation under unsaturated soil moisture conditions (personal communication with National Fertilizer Secretariat, 2017). Nitrification, conversion of $\mathrm{NH}_{4}{ }^{+}$to $\mathrm{NO}_{3}{ }^{-}$, is a biological transformation occurring predominantly under unsaturated soil moisture conditions since it is mediated by aerobic microorganisms. Thus, fertilize- $\mathrm{N}$ is converted to $\mathrm{NO}_{3}{ }^{-}-\mathrm{N}$ in soils at different rates depending upon the dynamics of soil nitrifiers. Krishnapillai (1979)

\footnotetext{
1 Horticultural Crops Research and Development Institute, Gannoruwa, Peradeniya, Sri Lanka

2 Department of Soil Science, Faculty of Agriculture, University of Peradeniya, Sri Lanka

* Corresponding author: warshisd@pdn.ac.lk
} 
reported that about 35 - 50\% of the ammonium and urea fertilizer applied to soils in tea plantations in Sri Lanka were nitrified within 3 to 4 weeks after application and the produced $\mathrm{NO}_{3}{ }^{-}$rapidly leached from soil under high rainfall condition. In Sri Lanka, Nuwara Eliya, Kalpitiya and Marassana are some of the intensively vegetable grown regions that experience heavy application of nitrogen fertilizers. According to Jayasingha et al. (2011) $\mathrm{NO}_{3}^{-}-\mathrm{N}$ in 50 $\%$ of the studied groundwater samples collected from Kalpitiya exceeded WHO standards for drinking water $\left(10 \mathrm{mg} \mathrm{L}^{-1}\right)$ both in dry season and rainy season with values ranging from 0.20 $212.4 \mathrm{mg} \mathrm{L}^{-1}$. A number of studies suggest association of $\mathrm{NO}_{3}{ }^{-}-\mathrm{N}$ in groundwater with fertilizer-N usage for vegetable cropping in the region threatening human health (Henegama et al., 2013; Kuruppuarachchi, 2010; Jayasingha et al., 2011; Liyanage et al., 2000). However, little or no information is available on the diversity and dynamics of nitrifiers inhabiting soils of Sri Lanka.

Biological nitrification was first explained by Winogradsky during 1889-1890 describing the role of nitrifying bacteria. Two chemoautotrophic groups of bacteria broadly known as ammonia oxidizers (e.g. Nitrosomonas spp., Nitrosospira spp., Nitrsococcus spp., etc.) and nitrite oxidizers (Nitrobacter spp., Nitrospira spp., Nitrococcus spp., etc.) are known to oxidize ammonia into nitrite and subsequently nitrite into nitrate (Schmidt, 1982). However, presence of ammonia oxidizing archaea (AOA) in soil have been detected and several studies suggest that AOA may play an important role in nitrification under low ammonium concentrations and/or under suboptimal conditions defined for ammonia oxidizing bacteria (AOB), such as acidic $\mathrm{pH}$, high EC, and low temperature (Leininger et al., 2006; Bernhard et al., 2010; Hofferle et al., 2010; Posser and Nicol, 2012; Hu and He, 2014). Further complete oxidation of ammonia to nitrate by a single organism via a process known as complete ammonia oxidation or comammox has been detected in some members of Nitrospira genus although the responsible microorganisms have not been isolated (Kessel et al., 2015). Organisms exhibiting comammox are considered to be having slow growth rates. Beeckman et al. (2018) also emphasized about ammonia oxidizing Achaea and comammaox bacteria who play a critical role in nitrification. Decaying organic matter, biologically fixed $\mathrm{NH}_{4}{ }^{+}$and added fertilizers provide $\mathrm{NH}_{4}{ }^{+}-\mathrm{N}$, the substrate for nitrification (Sylivia et al., 2005). Ammonia oxidizing bacteria seems to govern nitrification under $\mathrm{NH}_{4}{ }^{+}-\mathrm{N}$ rich soil conditions such as in soils that received fertilizer-N, polluted with sewage sludge, or experienced leakages from septic tanks (Leininger et al., 2006; Höfferle, et al., 2010).

Both $\mathrm{NO}_{3}{ }^{-}$and $\mathrm{NH}_{4}{ }^{+}$are considered as plant available forms of $\mathrm{N}$ though $\mathrm{NO}_{3}{ }^{-}$is a mobile ion subjected to leaching and loss from soil through denitrification. Hence, nitrification rate determines how quick the $\mathrm{N}$ is becoming unavailable for crop uptake when provides $\mathrm{NH}_{4}{ }^{+}$ through fertilizers in agriculture field. Potential nitrification rate (PNR) is a measure used to identify rapidity of nitrification with the provision of ample amount of $\mathrm{NH}_{4}{ }^{+}$which converts $\mathrm{NH}_{4}{ }^{+}$into $\mathrm{NO}_{3}{ }^{-}$in the presence of nitrifying communities for a particular soil. Enumeration of ammonia oxidizers and nitrite oxidizers coupled with most probable number (MPN) technique is commonly used to estimate the abundance of these two groups (Prosser and Nicol, 2012; Hesselsoe et al., 2001). Both PNR and MPN techniques do not discriminate between archaeal and bacterial counterparts (Prosser and Nicol, 2012) but found to be more representative of bacterial nitrifiers under $\mathrm{NH}_{4}{ }^{+}-\mathrm{N}$ rich soil conditions (Hofferle et al., 2010). Although these techniques provide a fairly good understanding about soil nitrifiers the anomalies common for culture based techniques should be considered when interpret results.

Intensive vegetable cultivation is practiced in several agro ecological regions in Sri Lanka in varying intensity and types of input management with different crop rotations leading to high diversity in vegetable grown systems. Therefore, we hypothesized that the abundance and the 
activity of nitrifiers in soils will be different across different vegetable grown systems. This study was conducted to estimate the activity of nitrifiers and their abundance in soils from selected intensively vegetable cultivated regions using PNR and MPN techniques to generate preliminary information on dynamics of nitrifiers in these systems. The information will be useful in future research and planning activities to enhance $\mathrm{N}$-fertilizer use efficiency and minimize $\mathrm{NO}_{3}{ }^{-}$leaching to groundwater. Further this study attempted to enumerate and isolate nitrifying bacteria for future research.

\section{METHODOLOGY}

Vegetable production under different input management systems in different agro-ecological regions were selected in order to introduce high diversity of systems to the study. Accordingly, four locations having contrasting climatic conditions and soil types, and also representing popular regions for vegetable production in the country, were selected. Introducing variability in input management, uncultivated lands under natural vegetation, vegetable cultivated fields managed conventionally using synthetic agrochemicals, and those managed with organic farming methods were included in the sampling scheme whenever possible. Details of the locations used for soil sampling is given in Figure 1 and Table 1.

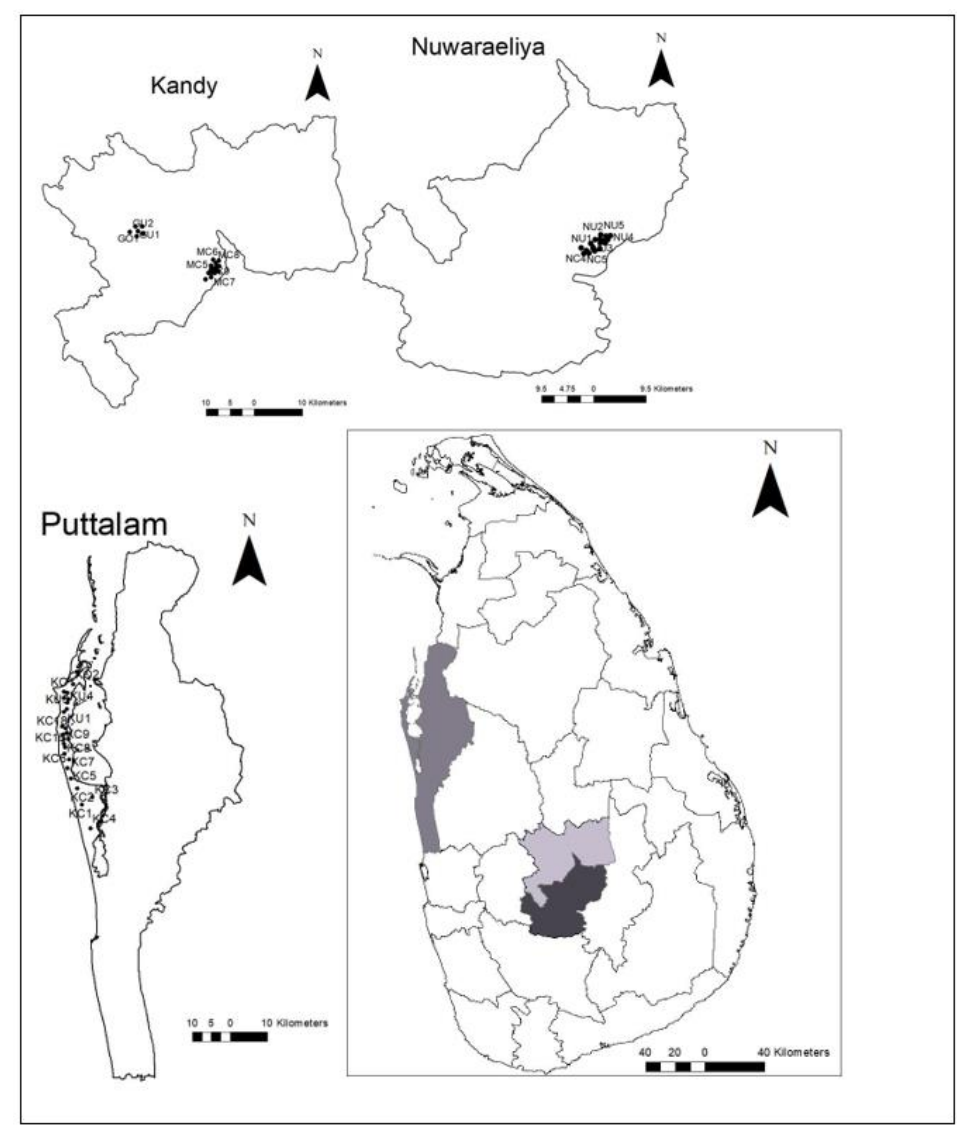

Figure 1. Map of Sri Lanka depicting sampling locations in three districts 
Table 1. Details of the sampling locations and the number of samples collected from each location

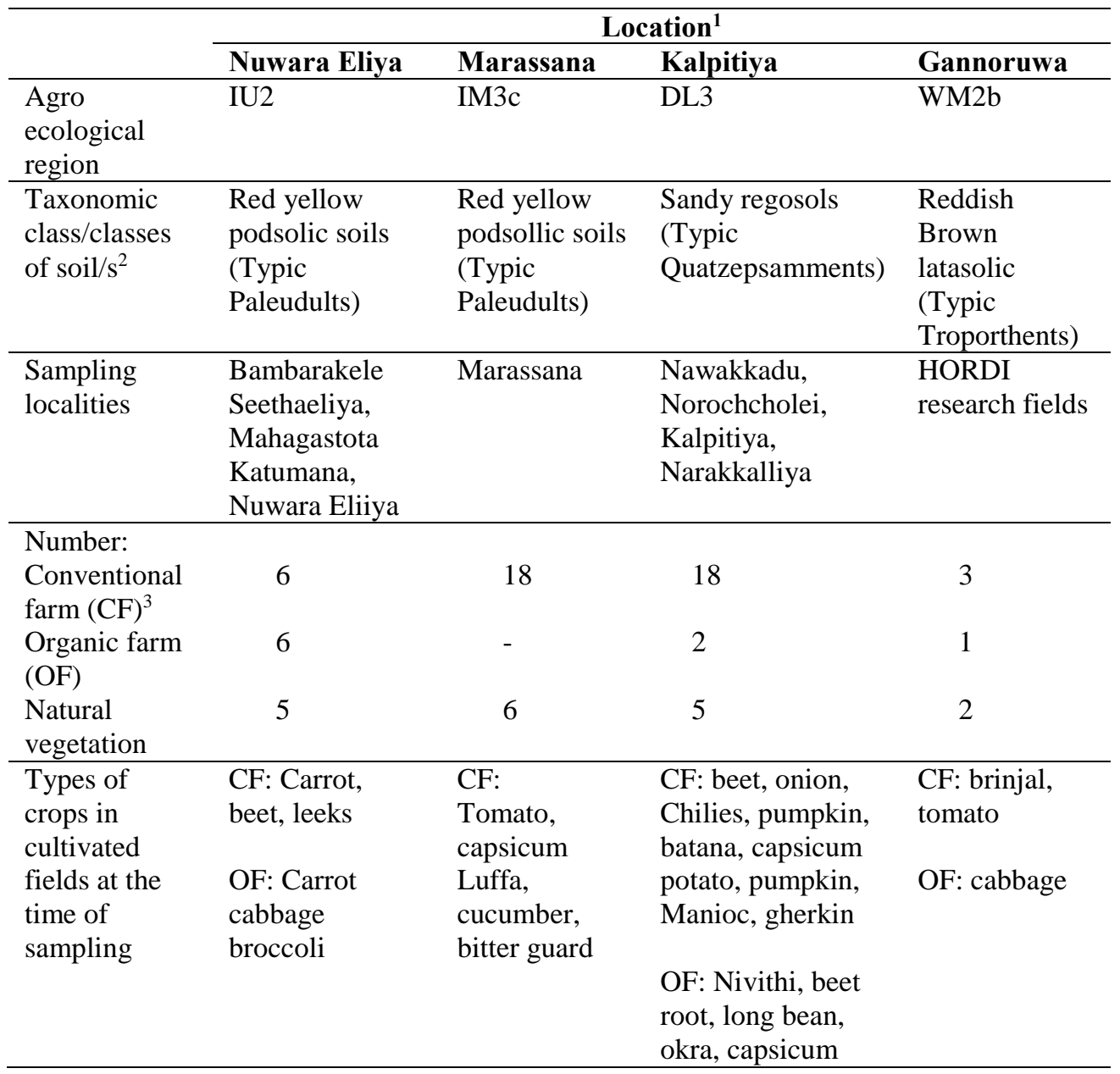

Sampling was performed for 4 months, from October, 2016 to March in 2017. Selected vegetable cultivated fields were having a crop at maturity stage at the time of sampling. From each field eight random soil samples were collected at $0-15 \mathrm{~cm}$ depth to make a composite sample representative of the field. Altogether 72 soil samples were collected for the study. Soil samples were immediately transferred to the laboratory at HORDI, Peradeniya, Sri Lanka. A subsample of the field moist soil was sieved through $4 \mathrm{~mm}$ sieve and refrigerated for subsequent microbial analyses. The remaining portion of each soil sample was air dried, sieved through $2 \mathrm{~mm}$ mesh sieve and stored for chemical and physical characterization.

\section{Physico-chemical Analyses}

Soil $\mathrm{pH}$ and electrical conductivity (EC) were measured in soil: water suspensions of 1:1 and 1:5, respectively. Soil organic carbon was analyzed using Walkley and Black method (Baruah and Barthakur, 1997) and active carbon content was analyzed according to permanganate 
oxidiazable carbon (POXC) method described by Weil et al. (2003). Soil texture was determined by pipette method as explained in Dharmakeertihi et al. (2007).

\section{Microbiological analyses}

Soils were analyzed for total culturable bacteria, fungi, ammonia oxidizing bacteria and nitrite oxidizing bacteria using culture based techniques. Total culturable bacteria and fungi were enumerated on $3 \%$ triptic soy agar (TSA) and Rose Bengal agar, respectively, using serial dilutions in spread plate technique. Plates were incubated at $28 \pm 1{ }^{\circ} \mathrm{C}$ and bacterial colony counts were taken 2 days after inoculation and fungal colonies were counted 6 days after inoculation. Most probable number (MPN) method as described by Schmidt and Belser (1994) was used to estimate the abundance of ammonia oxidizers and nitrite oxidizers. Cultures were incubated in triplicates for 21 days before making observations. Potential Nitrification Rate (PNR) of soils was assessed following shaken slurry method (Heart et al., 1995). Optimum time points to collect subsamples for the determination of potential nitrification rates were identified after conducting a preliminary study. Accordingly subsamples of the slurry was drawn at $4 \mathrm{~h}$ and $20 \mathrm{~h}$ after initiating incubation at room temperature $\left(26 \pm 2{ }^{\circ} \mathrm{C}\right)$ and nitrate was measured calorimetrically (Cataldo et al.,1975). Ammonia oxidizers were cultured in $\mathrm{NH}_{4}{ }^{+}$ containing $\mathrm{P}$ buffer medium used in MPN method and plated on to TSA to obtain single colonies. Selected colonies were purified and screened for their ability to oxidize $\mathrm{NH}_{4}{ }^{+}$. Isolates of ammonia oxidizers were cultured in $\mathrm{NH}_{4}{ }^{+}$containing $\mathrm{P}$ buffer medium and stored in refrigerator for future analyses.

\section{Statistical Analysis}

All the statistical analyses were performed using SPSS 16 statistical package. Data collected were used in preliminary descriptive analysis and Pearson correlation analysis for the measured parameters was performed at $\mathrm{p}<0.05$. Principal component analysis (PCA) was performed to identify the variables among the measured parameters contributing mostly for the differences among soils. In here, correlation PCA was performed and the suitability of the data set for the structure detection was confirmed by performing Kaiser-Meyer-Olkin (KMO) Test and Bartlett's test of sphericity. Results indicated that sampling was adequate for factor analysis $(\mathrm{KMO}$ test value $=0.62)$ and there is adequate relationship between variables for structure detection (significance level at $<0.001$ ). Parallel analysis was performed to confirm the number of components to be retained from PCA and accordingly first three principal components (PC) were selected and single scores for each component for soil sample was calculated considering the variables contributing mostly to each PC to present data graphically.

\section{RESULTS AND DISCUSSION}

Soil samples collected from the four regions belonging to different climatic regions and having different soil types as indicated in Table 1 were diverse in terms of measured soil characteristics (Table 2). The $\mathrm{pH}$ of the studied soils ranged from very strongly acidic (3.8) to moderately alkaline (8.5). High variability in $\mathrm{pH}$ was observed even within the same management system in a region (e.g.CF in Nuwara Eliya) possibly due to multitude of factors including differences in topography and intensity of input management. Majority of the soil samples from Nuwara Eliya region were acidic while $92 \%$ of soils found in Kalpitiya were alkaline but none of the studied soils were saline (Table 2). Organic C percentages were high in $56 \%$ of the soil samples from Nuwara Eliya. In contrast, $60 \%$ of soils from Kalpitiya had 
Table 2. Basic statistics of chemical properties of soil collected from Nuwara Eliya, Gannoruwa, Marassana and Kalpitiya

\begin{tabular}{|c|c|c|c|c|c|c|c|c|c|c|c|}
\hline Location & GC & GO $^{\#}$ & GU & KC & KO & KU & MC & MU & $\mathrm{NC}$ & NO & $\mathbf{N U}$ \\
\hline $\begin{array}{l}\text { Number } \\
\text { of } \\
\text { samples }\end{array}$ & 3 & 1 & 2 & 18 & 2 & 5 & 18 & 6 & 6 & 6 & 5 \\
\hline \multicolumn{12}{|c|}{ pH } \\
\hline Mean & 6.6 & 6.7 & 6.3 & 7.6 & 7.8 & 7.7 & 6.6 & 6.9 & 5.6 & 6.5 & 4.9 \\
\hline St. Dev. & 0.5 & - & 0.1 & 0.5 & 0.1 & 1.0 & 0.6 & 0.4 & 1.1 & 0.2 & 1.1 \\
\hline Minimum & 6.2 & - & 6.3 & 6.4 & 7.7 & 6.0 & 5.2 & 6.1 & 4.5 & 6.3 & 3.8 \\
\hline Maximum & 7.2 & - & 6.4 & 8.5 & 7.9 & 8.3 & 7.2 & 7.2 & 7.3 & 6.8 & 6.5 \\
\hline \multicolumn{12}{|c|}{ EC $(d S / m)$} \\
\hline Mean & 0.19 & 0.06 & 0.08 & 0.12 & 0.13 & 0.25 & 0.25 & 0.18 & 0.37 & 0.2 & 0.12 \\
\hline St. Dev & 0.02 & - & 0.004 & 0.04 & 0.03 & 0.14 & 0.22 & 0.03 & 0.2 & 0.12 & 0.02 \\
\hline Minimum & 0.17 & - & 0.08 & 0.06 & 0.10 & 0.09 & 0.04 & 0.10 & 0.12 & 0.13 & 0.09 \\
\hline Maximum & 0.06 & - & 0.23 & 0.15 & 0.15 & 0.43 & 0.94 & 0.18 & 0.58 & 0.44 & 0.14 \\
\hline \multicolumn{12}{|c|}{ Organic Carbon (\%) } \\
\hline Mean & 1.9 & 1.2 & 4.0 & 0.7 & 0.9 & 1.5 & 1.5 & 1.5 & 2.7 & 3.2 & 3.1 \\
\hline St. Dev. & 0.5 & - & 0.5 & 0.8 & 0.1 & 1.3 & 1.1 & 1.1 & 0.6 & 0.8 & 0.5 \\
\hline Minimum & 1.6 & - & 3.6 & 0.3 & 0.9 & 0.4 & 1.0 & 0.5 & 1.6 & 2.3 & 2.3 \\
\hline Maximum & 2.4 & - & 4.3 & 3.8 & 1.0 & 3.4 & 3.2 & 3.0 & 3.4 & 4.5 & 3.7 \\
\hline \multicolumn{12}{|c|}{ Active carbon (mg/kg) } \\
\hline Mean & 248 & 261 & 207 & 257 & 395 & 457 & 307 & 419 & 290 & 371 & 563 \\
\hline St. Dev & 233 & - & 46 & 153 & 49 & 263 & 111 & 126 & 155 & 213 & 138 \\
\hline Minimum & 34 & - & 174 & 2 & 360 & 135 & 120 & 284 & 103 & 136 & 419 \\
\hline Maximum & 496 & - & 240 & 306 & 429 & 815 & 453 & 630 & 553 & 708 & 749 \\
\hline
\end{tabular}

Nuwara Eliya, Gannoruwa, Marassana and Kalpitiya are denoted by N, G, M and K, respectively as first letter in data labels representing uncultivated lands and fields cultivated with vegetables using conventional and organic practices (as denoted by $\mathrm{U}, \mathrm{C}$ and $\mathrm{O}$, respectively as second letter in data labels). " There was only one field sampled from Gannoruwa representing organic vegetable production. Therefore, standard deviation, minimum and maximum are not calculated

very low organic $\mathrm{C}$ content. In the present study, there was no clear effect of implementing organic management practices on soil organic $\mathrm{C}$ contents. This may be partly due to the less number of samples representing organically cultivated fields compared to conventionally managed fields. Active carbon quantifies labile carbon in soil (Culman et al., 2013). The amount of labile carbon influences the availability of readily utilizable carbon to microorganisms and hence, their activity (Hurisso et al., 2016). It is considered as a sensitive indicator of soil quality (Culman et al., 2013). The active carbon contents varied widely in analyzed soil samples (Table 2) and the values are within the range reported previously, which is from 24 to $1469 \mathrm{mg} \mathrm{kg}^{-1}$ (Culman et al., 2013; Hurisso et al., 2016). Soil texture was highly variable among the tested samples with sand contents ranging from 6 to $97 \%$. In overall, the most prominent textural classes of the studied soils were Sandy clay loam (34\%) and Sandy loam (30\%). The highest diversity in soil texture was found in samples collected from Marassana with Sandy clay loam, Sandy loam, Loam, Loamy sand and Sandy clay as the textural classes. Soil samples collected from Gannoruwa had Sandy clay loam texture. The texture of soil samples collected from Nuwara Eliya were mostly loamy type and belonged to 
textural classes of Sandy clay loam, Sandy loam, Silt loam, Loam and Clay loam. On the other hand, the soils collected from Kalpitiya region were mostly sandy type and belonged to textural classes of sandy clay loam, sandy loam, loamy sand and sand.

The potential activity of nitrifiers ranged from 0.1 to $16.0 \mathrm{NO}_{3}{ }^{-}-\mathrm{N} \mathrm{mg} / \mathrm{kg}$ of dry soil/ h (Figure 2a). Mostly conventionally managed fields showed higher PNR rate compared to other cropping histories in respective regions. This may be due to the higher ammonium levels applied by farmers. When analyzing total ammonia oxidizing bacteria and nitrite oxidizing bacteria referred to as nitrifying bacteria, above results cannot be explained subjected to population size of them (Figure $2 b$ and $2 c$ ). The efficiency of nitrifying communities under optimum conditions when expressed as potential nitrification rate per unit of ammonia oxidizers, who are conducting the rate limiting first step of nitrification, varied from 1 to $57,341 \mathrm{pg} \mathrm{NO}_{3}^{-}-\mathrm{N} /$ ammonia oxidizer cell/ $\mathrm{h}$ suggesting differences in species composition in these communities

Table 3. The abundance of total culturable bacteria and fungi in the soil collected from Nuwara Eliya, Gannoruwa, Marassana and Kalpitiya

\begin{tabular}{|c|c|c|c|c|c|c|c|c|c|c|c|}
\hline Location & NO & NC & NU & GO & GC & GU & MC & MU & KO & KC & $\mathbf{K U}$ \\
\hline \multicolumn{12}{|c|}{ Bacteria $\left(\log 10 \mathrm{CFU} \mathrm{g}^{-}\right)$} \\
\hline Mean & 8.1 & 7.9 & 7.8 & - & 7.7 & 8.35 & 8.2 & 8.1 & 8.8 & 8.6 & 8.9 \\
\hline St. Dev. & 0.3 & 0.2 & 0.2 & - & 0.2 & 0.01 & 0.2 & 0.2 & 0.1 & 0.2 & 0.5 \\
\hline Minimum & 7.69 & 7.7 & 7.6 & - & 7.6 & 8.34 & 7.5 & 7.8 & 8.7 & 8.1 & 8.6 \\
\hline Maximum & 8.5 & 8.2 & 8.1 & - & 7.9 & 8.36 & 8.5 & 8.4 & 8.9 & 9.0 & 9.9 \\
\hline \multicolumn{12}{|c|}{ Fungi $\left(\log 10\right.$ CFU $\left.\mathrm{g}^{-}\right)$} \\
\hline Mean & 4.1 & 3.7 & 3.6 & - & 3.2 & 3.3 & 3.3 & 4.9 & 4.5 & 4.5 & 4.4 \\
\hline St. Dev. & 0.8 & 0.5 & 0.2 & - & 0.2 & 0.0 & 0.3 & 0.10 & 0.1 & 0.4 & 0.1 \\
\hline Minimum & 3.3 & 3.1 & 3.4 & - & 3.0 & 3.3 & 2.7 & 4.8 & 4.4 & 3.6 & 4.2 \\
\hline Maximum & 5.2 & 4.4 & 3.9 & - & 3.0 & 3.3 & 3.9 & 5.1 & 4.5 & 4.9 & 4.5 \\
\hline
\end{tabular}

Nuwara Eliya, Gannoruwa, Marassana and Kalpitiya are as denoted by N, G, M and K, respectively as first letter in data labels representing uncultivated lands and fields cultivated with vegetables using conventional and organic practices (as denoted by $\mathrm{U}, \mathrm{C}$ and $\mathrm{O}$, respectively as second letter in data labels)

Loamy type textures usually facilitate good air and water balance while soils with sandy type textures are highly aerated and have less water retention. When water retention in soil is poor it affects substrate diffusion to microbial cells and cause adverse physiological effects due to cell dehydration; thus, affecting nitrification (Stark and Firesotne 1995). Further, oxidation of organic matter is high in well aerated soils than poorly aerated soils when moisture level is not limiting microbial activity and therefore, organic matter retention is less in sandy type texture compared to loamy or clayey type soil textures. Significant negative correlations between sand content of soils and the organic carbon and active carbon contents were seen in the present study (Table 4). Soil pH correlated with a number of parameters measured (Table 4). Therefore, the nitrifying communities of the studied soils may have evolved under unique sets of environmental constraints as facilitated by interacting effects of soil properties like texture, pH and organic carbon contents with agro-climatic conditions (O'Sullivan et al., 2013). 
Population size of nitrite oxidizers were higher compared to ammonia oxidizers (Figure 2b.and 2c.). Sergei Winogradsky first isolated and showed in 1890 the organisms responsible for two steps of nitrification. $1^{\text {st }}$ step is carried out by mainly Nitrosomonas, Nitrosospira, Nitrosolobus, and Nitrosococcus. Second step is carried out by mainly Nitrobactor, followed by Nitrospira and Nitrosococcus (Sullivan et al., 2012). However, recent studies indicated that some members of genera Nitrospira could perform complete oxidation of $\mathrm{NH}_{4}{ }^{+}$to $\mathrm{NO}_{3}$ via comammox (Kessel et al., 2015).

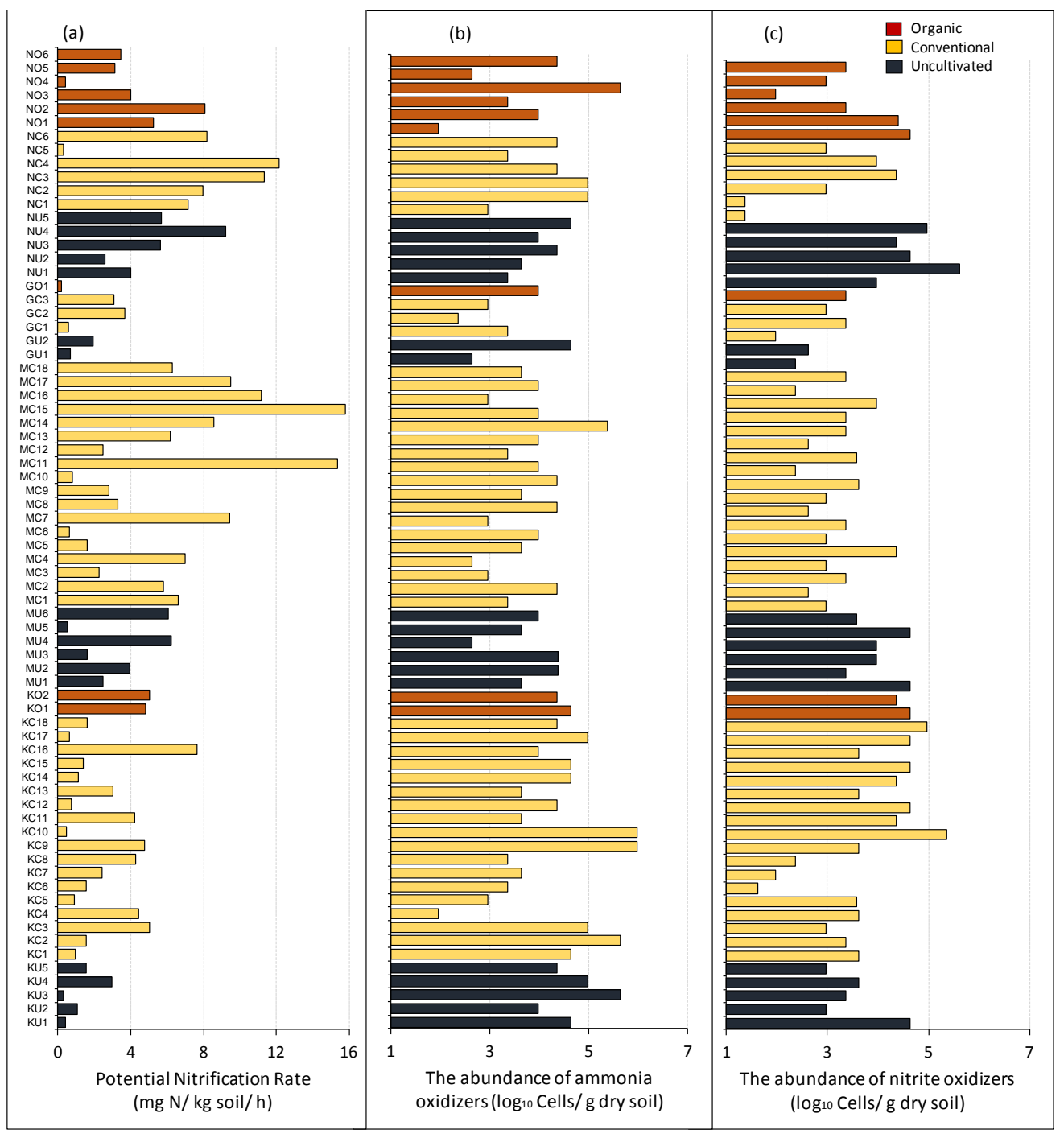

Figure 2. The activity and abundance of nitrifiers as indicated by (a) potential nitrification rate (mg of nitrate $\mathrm{N} / \mathrm{kg}$ of dry soil /h) (b) abundance of ammonia oxidizers and (c) abundance of nitrite oxidizers of the soils collected from Nuwara Eliya, Gannoruwa, Marassana and Kalpitiya (as denoted by N, G, M and $K$, respectively as first letter in data labels) representing uncultivated lands and fields cultivated with vegetables using conventional and organic practices (as denoted by $\mathrm{U}, \mathrm{C}$ and $\mathrm{O}$, respectively as second letter in data labels)

Nitrospira could be found in high abundance in soil but their activity is very slow compared to Nitrosomonas like species (van Kessel et al., 2015). Further, AOB like Nitrosomonas spp. 
frequently found in agricultural soils are metabolically classified as obligate chemolithoautotrophs that utilize $\mathrm{NH}_{4}{ }^{+}$as an energy source and $\mathrm{CO}_{2}$ as the $\mathrm{C}$ source. Increase in activity of this organism in the presence of organic substrates has been reported (Hommes et al., 2003). Therefore, the activity of the same group of organism could be different with respect to soil environmental characters such as composition and availability of labile carbon.

Techniques used in the present study to analyze PNR and the abundance of nitrite oxidizers and ammonia oxidizers do not discriminate between bacterial and archaeal counterparts (Prosser and Nicol, 2012). However significant differences in terms of the contribution of these two groups of organisms for nitrification have been suggested based on molecular based approaches in a number of studies (Leininger et al., 2006; Bernhard et al., 2010; Hofferle et al., 2010; Posser and Nicol 2012; $\mathrm{Hu}$ and He, 2014). Bacterial nitrifiers are reported to dominate nitrification under slightly acidic to neutral $\mathrm{pH}$ soil conditions and also under environments receiving high $\mathrm{NH}_{4}{ }^{+}$inputs (Fan et al., 2011; Tylor et al., 2011; Verhamme et al., 2011). According to Tylor et al. (2011) fertilizer-N application and manure addition increased AOB abundance in soils compared to unfertilized soils while AOA abundance remained unchanged. However, the community composition of both AOB and AOA groups changed with fertilizer treatments. They further reported that change in community composition of AOB with crop growth stage was more prominent than that of AOA. Therefore, there should be high variability in the dominance of $\mathrm{AOB}$ and AOA in the studied soils that represent uncultivated and cultivated systems, which are different with respect to input management and vegetation.

Higher number of archaeal nitrifiers have been reported under extreme soil conditions for microbial growth such as high or low pH, salinity, etc. (Bernhard et al., 2010; Hofferle et al., 2010; Posser and Nicol 2012; Hu and He, 2014). Change in abundance of these two groups depending on temperature and soil moisture regimes and altitude has also been reported (O'Sullivan et al., 2013; Tylor et al., 2011; Zhang et al., 2009). The altitude of the sampling sites used in the present study varied from $8 \mathrm{~m}$ (e.g. Kalpitiya) to above $1860 \mathrm{~m}$ (e.g. Nuwara Eliya) from mean sea level and along with the elevation gradient the climatic conditions the soils are experiencing changes as indicated by the different agro-ecological regions the locations belong to (Table 1). Further high diversity in soil texture is suggestive of high variability in temperature and moisture conductivity among many other processes affecting microbial growth. Therefore, it can be expected that even though two soils have relatively similar abundance of ammonia oxidizers the activity can be very different because composition of community affects the potential activity. This is evident in the present study since the abundance of ammonia oxidizers in soils collected from Kalpitiya and Marassana are less variable compared to the variability exist in the potential activity of nitrifiers from the same soils (Figure 1a and 1b). Potential nitrification rate is often reported to show correlation with AOB abundance than AOA (Bernhard et al., 2010). Lack of correlation between PNR and AOA and AOB abundance was observed by O'Sullivan et al. (2013). In the present study, significant correlation was observed between PNR and EC but there was no correlation between PNR and the abundance of either ammonia oxidizer or nitrite oxidizer groups (Table 4). There may be differences in terms of the contribution of AOA and AOB for the nitrification in soils used in present study.

Although there is high variability in the estimated characters of the nitrifying populations these characters were not strong at defining the variability of the studied soils as indicated by PCA (Table 5 and 6). The variability among the studied soils was captured by PC1, PC2 and PC3 at 30,16 and $14 \%$, respectively. Structure of data along PC1 is mostly due to soil $\mathrm{pH}$ and 
organic $\mathrm{C}$ and abundance of bacteria and fungi. Potential nitrification rate and EC scored high in PC2. O'Sullivan et al. (2013) reported that PNR was more sensitive to the soil fertility status than the population sizes of AOA and AOB. In the present study PNR contributed for the variability of studied soils than ammonia oxidizer or nitrite oxidizer abundance as depicted by PCA.

Despite the differences in soil characteristics and agro-climatic conditions, the studied vegetable production systems have one character in common, which is intensive production with high input use (organic and/or synthetic fertilizers). Therefore, the soils receive high dose of nitrogenous fertilizers in each cropping cycle. The intensity of cultivation considering the number of crops per year vary as NuwaraEliya $>$ Kalpitiya $>$ Marassana=Gannoruwa. These regions are environmentally sensitive areas as Nuwara Eliya, Gannoruwa and Marassana are in tributaries of major rivers (mainly river Mahaweli) and Kalpitiya is located on a perched water table. Therefore, contamination of groundwater and surface water bodies with nitrate causing on-site and off-site effects is highly probable in these regions.

Table 4. Correlations between measured variables

\begin{tabular}{|c|c|c|c|c|c|c|c|c|c|}
\hline & pH & EC & OC & $\mathrm{AC}$ & PNR & TB & TF & AO & NO \\
\hline $\mathrm{EC}$ & $\begin{array}{l}-0.137 \\
N S\end{array}$ & & & & & & & & \\
\hline $\mathrm{OC}$ & $\begin{array}{l}-0.490 \\
* * *\end{array}$ & $\begin{array}{l}0.126 \\
N S\end{array}$ & & & & & & & \\
\hline $\mathrm{AC}$ & $\begin{array}{l}-0.175 \\
N S\end{array}$ & $\begin{array}{l}-0.039 \\
N S\end{array}$ & $\begin{array}{l}0.183 \\
N S\end{array}$ & & & & & & \\
\hline PNR & $\begin{array}{l}-0.225 \\
*\end{array}$ & $\begin{array}{l}0.547 \\
* * *\end{array}$ & $\begin{array}{l}0.193 \\
\text { NS }\end{array}$ & $\begin{array}{l}0.109 \\
\text { NS }\end{array}$ & & & & & \\
\hline TB & $\begin{array}{l}0.500 \\
* * *\end{array}$ & $\begin{array}{l}-0.060 \\
N S\end{array}$ & $\begin{array}{l}-0.339 \\
* *\end{array}$ & $\begin{array}{l}0.034 \\
N S\end{array}$ & $\begin{array}{l}-0.237 \\
*\end{array}$ & & & & \\
\hline $\mathrm{TF}$ & $\begin{array}{l}0.296 \\
*\end{array}$ & $\begin{array}{l}-0.214 \\
*\end{array}$ & $\begin{array}{l}-0.297 \\
*\end{array}$ & $\begin{array}{l}0.044 \\
N S\end{array}$ & $\begin{array}{l}-0.389 \\
* *\end{array}$ & $\begin{array}{l}0.361 \\
* *\end{array}$ & & & \\
\hline $\mathrm{AO}$ & $\begin{array}{l}0.200 \\
N S\end{array}$ & $\begin{array}{l}-0.075 \\
N S\end{array}$ & $\begin{array}{l}-0.175 \\
N S\end{array}$ & $\begin{array}{l}0.163 \\
N S\end{array}$ & $\begin{array}{l}-0.084 \\
N S\end{array}$ & $\begin{array}{l}0.282 \\
*\end{array}$ & $\begin{array}{l}0.329 \\
* *\end{array}$ & & \\
\hline NO & $\begin{array}{l}0.157 \\
N S\end{array}$ & $\begin{array}{l}-0.263 \\
*\end{array}$ & $\begin{array}{l}-0.096 \\
N S\end{array}$ & $\begin{array}{l}0.203 \\
N S\end{array}$ & $\begin{array}{l}-0.116 \\
N S\end{array}$ & $\begin{array}{l}-0.021 \\
N S\end{array}$ & $\begin{array}{l}0.021 \\
N S\end{array}$ & $\begin{array}{l}0.146 \\
N S\end{array}$ & \\
\hline sand $\%$ & $\begin{array}{l}0.49 \\
* * *\end{array}$ & $\begin{array}{l}0.001 \\
N S\end{array}$ & $\begin{array}{l}-0.51 \\
* * *\end{array}$ & $\begin{array}{l}-0.496 \\
* * *\end{array}$ & $\begin{array}{l}0.014 \\
N S\end{array}$ & $\begin{array}{l}0.004 \\
N S\end{array}$ & $\begin{array}{l}0.18 \\
N S\end{array}$ & $\begin{array}{l}-0.11 \\
N S\end{array}$ & $\begin{array}{l}-0.16 \\
N S\end{array}$ \\
\hline
\end{tabular}

OC-organic carbon, AC-active carbon, PNR-potential nitrification rate, TB-total bacteria, TF-total fungi, AOammonia oxidizers, NO-nitrite oxidizers

NS - Not significant:

Significance at probability levels: $p<0.05, *: p<0.01$, **: $p<0.001$, ***

Table 5. Total Variance explained by the first three principal components (PCs)

\begin{tabular}{llll}
\hline \multirow{2}{*}{ Component } & \multicolumn{3}{l}{ Initial Eigenvalues } \\
\cline { 2 - 4 } & Total & \% of Variance & Cumulative \% \\
\hline 1 & 2.758 & 30.645 & 30.645 \\
2 & 1.435 & 15.940 & 46.585 \\
3 & 1.290 & 14.331 & 60.916 \\
\hline
\end{tabular}


Table 6. Scores of each variable in Rotated Component Matrix

\begin{tabular}{llll}
\hline \multirow{2}{*}{ Variable } & Component & & \\
\cline { 2 - 4 } & $\mathbf{1}$ & $\mathbf{2}$ & $\mathbf{3}$ \\
\hline Bacteria abundance & 0.797 & 0.013 & 0.126 \\
$\mathrm{pH}$ & 0.751 & -0.119 & -0.109 \\
Organic C & -0.683 & 0.106 & 0.202 \\
Fungi abundance & 0.668 & -0.243 & 0.120 \\
EC & -0.042 & 0.877 & -0.072 \\
Potential nitrification rate & -0.280 & 0.796 & 0.101 \\
Active C & -0.176 & 0.062 & 0.829 \\
Ammonia oxidizer abundance & 0.483 & 0.043 & 0.566 \\
Nitrite oxidizer abundance & -0.005 & -0.423 & 0.497 \\
\hline
\end{tabular}

There are enough evidences to indicate nitrate pollution in surface and ground water due to fertilizer usage in vegetable production is already an issue (Henegama et al., 2013; Kuruppuarachchi, 2010; Jayasingha et al., 2011; Liyanage et al., 2000). Therefore, information on potential activity of nitrifiers and the diversity of nitrifying communities are important to design suitable techniques to manage $\mathrm{N}$ fertilizers and minimize $\mathrm{N}$ losses to the environment.

From among the parameters estimated in relation to nitrifiers, PNR was the only parameter that contributed to the structured variability among soils (Table 5 and 6). Based on the PNR values observed in the present study about $48 \%$ of soils had PNR values from 3 to $10 \mathrm{mg}$ of $\mathrm{N} / \mathrm{kg}$ soil $/ \mathrm{h}$ and $7 \%$ of soils had values greater than $10 \mathrm{mg}$ of $\mathrm{N} / \mathrm{kg}$ soil $/ \mathrm{h}$. Olsson and Falkengren-Grerup (1999) reported PNR in soils from Oak forests in Southern Sweden ranging from 0 to $24 \mathrm{nmol} \mathrm{NO}_{3}{ }^{-} / \mathrm{g} / \mathrm{h}$ which is equivalent to 0 to $0.34 \mathrm{mg}$ of $\mathrm{N} / \mathrm{kg} / \mathrm{h}$. They further reported that PNR positively correlated with $\mathrm{pH}$. Tylor et al. (2011) reported PNR rates as high as $2.4 \mu \mathrm{mol} \mathrm{N} / \mathrm{g} /$ day (equivalent to $1.46 \mathrm{mg}$ of $\mathrm{N} / \mathrm{kg}$ soil $/ \mathrm{h}$ ) when soil is incubated with 1 $\mathrm{mM} \mathrm{NH}{ }_{4}{ }^{+}$supplement. Based on a study conducted on an Alfisol soil in Northeast China, Fan et al. (2011) indicated that PNR tend to be suppressed by long term mineral fertilizer application but enhanced by application of manures such as horse manure. The reported PNR rates by Fan et al. (2011) ranged from 0.5 to $2.6 \mathrm{mg} \mathrm{NO}_{3}{ }^{-} / \mathrm{kg}$ soil $/ \mathrm{h}$ (equivalent to 0.11 to 0.59 $\mathrm{mg}$ of $\mathrm{N} / \mathrm{kg}$ soil $/ \mathrm{h}$ ). Therefore, PNR in most of the soils in this study are higher than those reported in literature (Figure 2a). Considering the high PNR values observed in the present study in agricultural soils there is a high potential of losing $\mathrm{N}$ once nitrogenous fertilizer are added to cultivated fields, contaminating groundwater and surface water with $\mathrm{NO}_{3}{ }^{-}$, and increasing emissions of $\mathrm{N}_{2} \mathrm{O}$, a greenhouse gas with 296 times more global warming potential than $\mathrm{CO}_{2}$ (Dalal et al., 2003). The $\mathrm{N}_{2} \mathrm{O}$ is emitted during nitrification to some extent and largely through denitrification of $\mathrm{NO}_{3}$ - produced from nitrification (Dalal et al., 2003). Hence timely actions are needed to be taken to moderate nitrification rate as vegetable grown regions receive high quantities of nitrogen fertilizers. Nine ammonia oxidizer isolates were made from the studied soils to facilitate future research activities on developing suitable techniques to suppress nitrification in vegetable cropping systems.

In the present study, the abundance of bacteria, fungi, ammonia oxidizers and nitrite oxidizers are presented in per gram of soil basis, which is a standard expression used. However, differences in patterns can be expected if the same has been presented in per unit soil volume because the soil texture and organic matter content vary widely across soils and structural properties, especially bulk density, also vary across fields (Mehlich, 1972). Since soil bulk density measurements were not made the comparison in per volume basis cannot be performed. 
It is suggested that in future research of this nature it will be important to consider expressing results in per volume of soil.

\section{CONCLUSIONS}

The soil characteristics, potential activity and abundance of nitrifiers' populations varied widely across the studied soils. The results indicate very high diversity in nitrifying communities inhabiting intensively vegetable cultivated soils. PNR contributed more to structuring the variability of soils than abundance of ammonia oxidizers and nitrite oxidizers, thus, it is a better indicator of dynamics of nitrifiers than population size of the group. It is revealed that potential nitrification rates of $55 \%$ of soils from the studied vegetable grown regions were higher than the values reported in literature. Hence, moderation of nitrification rate should be crucial, especially in vegetable grown soils, to improve agronomic fertilizer use efficiency and reduce groundwater contamination with nitrate and emissions of $\mathrm{N}_{2} \mathrm{O}$ as these fields receive high amounts of nitrogen fertilizers with each cropping cycle. The variability in soils with respect to functional diversity of nitrifying communities may have to be considered when developing mechanisms for the moderation of nitrification.

\section{REFERENCES}

Baruah, T.C and Barthakur. H.P. (1997). a text book of soil analysis. Vikas publishing house Pvt. Ltd. New Delhi.

Beeckman, F., Motte, H. and Beeckman, T. (2018). Nitrification in agricultural soils: impact, actors and mitigation, Current Opinion in Biotechnology. 50, 166-173.

Cataldo, D.A., Haroon, M. Schrader,L,E., and Youngs, V.L. (1975), Rapid colorimetric determination of nitrate in plat tissue by nitration of salicylic acid. Communications in Soil Science and Plant Analysis, 6(1), 71-80.

Culman, S. W., Snapp, S. S., Green, J. M., and Gentry, L. E. (2013). Short- and long-term labile soil carbon and nitrogen dynamics reflect management and predict corn agronomic performance. Agronomy Journal, 105:493-502. doi:10.2134/agronj2012.0382.

Dalal, R.C., Wang, W. Robertson, G.P. and Parton, W.J. (2003). Nitrous oxide emission from Australian agricultural lands and mitigation options: a review. Soil Research, 41(2), 165-195.

Dharmakeerthi, R.S., Indraratne,S.P. and Kumaragamage, D. (2007), Manual of Soil Sampling and Analysis, Special Publications, Soil Science Society of Sri Lanka.

Fan, F., Yang, Q., Li, Z., Wei, D., Cui, X.A. and Liang, Y. (2011). Impacts of organic and inorganic fertilizers on nitrification in a cold climate soil are linked to the bacterial ammonia oxidizer community. Microbial ecology, 62(4), 982-990.

Hart, S.C., Stark, J.M., Davidson, E.A. and Firestone, M.K. (1994). Nitrogen mineralization, immobilization and nitrification. pp. 985-1018.In: Weaver, R.W., Angle, J.S., and Bottomley, P.S. (Eds.) Methods of Soil Analysis, Part 2. Microbiological and Biochemical Properties. Soil Science Society of America. Madison, WI, USA. 
Henegama, H.P., Dayawansa, N.D.K. and De Silva, S. (2013). An Assessment of Social and Environmental Implications of Agricultural Water Pollution in Nuwara Eliya. Tropical Agricultural Research, 24(4), 304-316.

Hesselsøe, M., Brandt, K. K. and Sørensen, J. (2001). Quantification of ammonia oxidizing bacteria in soil using microcolony technique combined with fluorescence in situ hybridization (MCFU-FISH). FEMS microbiology ecology, 38(2-3), 87-95.

Höfferle, Š., Nicol, G. W., Pal, L., Hacin, J., Prosser, J. I. and Mandić-Mulec, I. (2010). Ammonium supply rate influences archaeal and bacterial ammonia oxidizers in a wetland soil vertical profile. FEMS microbiology ecology, 74(2), 302-315.

Hommes, N.G., Sayavedra-Soto, L.A. and Arp, D.J. (2003). Chemolithoorganotrophic growth of Nitrosomonas europaea on fructose. Journal of bacteriology, 185(23), 6809-6814.

Hu, H.W. and He, J.Z. (2014). Ammonia oxidizing Achaea play a predominant role in acid soil nitrification. Advances in Agronomy. 125, 261-302.

Hurisso, T. T., S. W. Culman, W. R. Horwath, J. Wade, D. Cass, J. W. Beniston, T. M. Bowles, A. S. Grandy, A. J. Franzluebbers, M. E. Schipanski, et al. (2016). Comparison of permanganate-oxidizable carbon and mineralizable carbon for assessment of organic matter stabilization and mineralization. Soil Science Society of America Journal, 80:1352-64. doi:10.2136/sssaj2016.04.0106.

van Kessel, M.A., Speth, D.R., Albertsen, M., Nielsen, P.H., den Camp, H.J.O., Kartal, B., Jetten, M.S. and Lücker, S. (2015). Complete nitrification by a single microorganism. Nature, 528(7583), 555-559.

Krishnapillai, S. (1979). Inhibition of nitirification by waste tea (tea fluff). Plant and Soil, 51, 563-569.

Kuruppuarachchi, D.S.P. (2010). A review on the leaching of nitrate from agricultural soil and pollution of ground water in Sri Lanka. Journal of Soil Science Society Sri Lanka, 22.

Leininger, S., Urich, T., Schloter, M., Schwark, L., Qi, J., Nicol, G.W., Prosser, J.I., Schuster, S.C. and Schleper, C. (2006). Archaea predominate among ammonia-oxidizing prokaryotes in soils. Nature, 442 (7104), 806-809.

Liyanage C. E., Thabrew, M. I. and Kuruppuarachchi D.S.P. (2000). Nitrate pollution in ground water of Kalpitiya: An evaluation of the content of nitrate in the water and food items cultivated in the area. Journal of National Science Foundation of Sri Lanka. 28(2), 101-112.

Mapa, R.B., Somasiri, S. and Dassanayake, A.R. (2010). Soils of the Dry zone of Sri Lanka, Soil Science Society of Sri Lanka.

Mapa, R.B., Somasiri S. and Nagarajah, S. (1999). Soils of the wet zone of Sri Lanka, Soil Science Society of Sri Lanka.

Mehlich, A. (1972). Uniformity of expressing soil test results a case for calculating results on a volume basis. Communications in Soil Science and Plant Analysis, 3(5), pp.417-424. 
Nicol, G.W. and Prosser, J.I. (2011). Strategies to determine diversity, growth, and activity of ammonia-oxidizing archaea in soil. In Methods in enzymology (Vol. 496, pp. 3-34). Academic Press.

O’Sullivan, C.A., Wakelin, S.A., Fillery, I.R. and Roper, M.M. (2013). Factors affecting ammonia-oxidising microorganisms and potential nitrification rates in southern Australian agricultural soils. Soil Research, 51(3), 240-252.

Olsson, M.O. and Falkengren-Grerup, U. (2000). Potential nitrification as an indicator of preferential uptake of ammonium or nitrate by plants in an oak woodland understorey. Annals of Botany, 85(3), 299-305.

Prosser, J. I. and Nicol, G. W. (2012). Archaeal and bacterial ammonia-oxidisers in soil: the quest for niche specialization and differentiation. Trends in microbiology, 20(11), 523-531.

Schmidt, E.L. (1982). Nitrification in Soil, In F.J. Stevenson (ed.), Nitrogen in Agricultural Soils, Agronomy Monograph No. 22, Madison WI, ASA-CSSA-SSSA, 253-288.

Schmidt, E.L. and Belser, L.W. 1994. Autotrophic nitrifying bacteria. In Methods of Soil Analysis, Part 2 Microbiological and Biochemical Properties. Eds. R.W. Weaver, J.S. Angle and P.S. Bottomley. Pp 59-79. Soil Science Society of America, Inc. Madison, WI, USA.

Sylvia, D.M., Fuhrmann, J.J., Hartel, P.G. and Zuberer, D.A. eds. (2005). Principles and applications of soil microbiology (No. QR111 S674 2005). Upper Saddle River, NJ: Pearson Prentice Hall.

Stark, J.M. and Firestone, M.K. (1995). Mechanisms for soil moisture effects on activity of nitrifying bacteria. Applied and environmental microbiology, 61(1), 218-221.

Sullivan, B.W., Selmants, P.C. and Hart, S.C. (2012). New evidence that high potential nitrification rates occur in soils during dry seasons: Are microbial communities metabolically active during dry seasons? Soil biology and biochemistry, 53, 28-31.

Taylor, A.E., Zeglin, L.H., Wanzek, T.A., Myrold, D.D. and Bottomley, P.J. (2012). Dynamics of ammonia-oxidizing archaea and bacteria populations and contributions to soil nitrification potentials. The ISME journal, 6(11), 2024-2032.

Verhamme, D.T., Prosser, J.I. and Nicol, G.W. (2011). Ammonia concentration determines differential growth of ammonia-oxidizing archaea and bacteria in soil microcosms. The ISME journal, 5(6), 1067-1071. 